\title{
A new species of the cave-fish genus Lucifuga (Ophidiiformes, Bythitidae), from eastern Cuba
}

\author{
Damir Hernández', Peter Rask Møller², Didier Casane ${ }^{3,4}$, Erik García-Machado, 1,5 \\ I Centro de Investigaciones Marinas, Universidad de La Habana, Calle 16, No. 114 entre 1 ra y 3ra, Miramar, \\ Playa, Ciudad Habana 11300, Cuba 2 Natural History Museum of Denmark, University of Copenhagen, \\ Universitetsparken 15, DK-2100 Copenhagen Ø, Denmark 3 Université Paris-Saclay, CNRS, IRD, UMR \\ Evolution, Génomes, Comportement et Écologie, 91198, Gif-sur-Yvette, France 4 Université Paris Diderot, \\ Sorbonne Paris Cité, 5 rue Thomas-Mann, 75205 Paris, France 5 Institut de Biologie Intégrative et des Sys- \\ tèmes, Université Laval, Québec, QC, GIV0A6, Canada
}

Corresponding author: Peter Rask Møller (pdrmoller@snm.ku.dk)

Academic editor: K. Piller | Received 22 February 2020 | Accepted 3 April 2020 | Published 6 July 2020

http://zoobank.org/6A134ED0-2FAC-483F-940B-6413D600FE55

Citation: Hernández D, Møller PR, Casane D, García-Machado E (2020) A new species of the cave-fish genus Lucifuga (Ophidiiformes, Bythitidae), from eastern Cuba. ZooKeys 946: 17-35. https://doi.org/10.3897/zookeys.946.51373

\begin{abstract}
Recently, a barcoding study and a molecular phylogenetic analysis of the Cuban species of the cave-fish genus Lucifuga Poey, 1858 revealed the existence of different evolutionary lineages that were previously unknown or passed unnoticed by morphological scrutiny (i.e., cryptic candidate species). In the present study, Lucifuga gibarensis is described as a new species restricted to anchialine caves in the northeastern karst region of the main island. The species was earlier described as a variety of Lucifuga dentata, but since the name was introduced as a variety after 1960, it is deemed to be infrasubspecific and unavailable according to the International Code of Zoological Nomenclature Art. 15.2. The new species differs from $L$. dentata by pigmented eyes vs. eyes absent and lack of palatine teeth vs. present. Lucifuga gibarensis seems to be most similar to the Bahamian species L. lucayana by showing pigmented eyes, 13 or 14 precaudal vertebrae and ten caudal fin rays. However, differs from it by a larger size of the pigmented eye (1.1-1.9 vs. $0.9-1.0 \% \mathrm{SL}$ ) and number of posterior lateral line neuromasts (30-33 vs. 34-35).
\end{abstract}

\section{Keywords}

Anchialine caves, Gibara, Holguin, speleology, taxonomy, viviparous brotulas

Copyright Damir Hernández et al. This is an open access article distributed under the terms of the Creative Commons Attribution License (CC BY 4.0), which permits unrestricted use, distribution, and reproduction in any medium, provided the original author and source are credited. 


\section{Introduction}

Lucifuga Poey, 1858 is a conspicuous genus of obligate cave-dwelling fishes, currently recognised with six species distributed in Cuba and Bahamas (Nielsen et al. 1999; Møller et al. 2006, 2016; see comparative material). Another nominal species, Lucifuga inopinata Cohen and McCosker, 1998, from off Galapagos Archipelago belongs to another, yet undescribed, genus (Møller unpublished data).

Because of the characteristics of the habitats of Lucifuga species (caves, sinkholes and crevices) and the morphological modifications that they show in the evolutionary adaptations to the environment, the genus represents an iconic part of the fish fauna in Cuba. The scientific interest in these fishes, however, has been sporadic. Since the description of the genus and the two first Cuban species by Felipe Poey (1858), the studies dealing with the genus are very few and have mainly been dedicated to the discussions of morphological characters of taxonomic interest for the genus and species and the descriptions of new species (Gill 1863; Nalbant 1981; Díaz-Pérez et al. 1987a, 1987b; Díaz-Pérez 1988); some aspects of feeding and reproductive system (Lane 1903; Eigenmann 1909; Thinès and Piquemal 1978; García-Debrás and Pérez 1999) and two studies that constituted the first approximation to the evolutionary relationships of the group based on a comparison of several morphological characters of the three species known at that time (Vergara 1980, 1981).

Møller et al. (2006) found evidence for all Cuban and all Bahamian species representing two separate evolutionary lineages, but recently García-Machado et al. (2011) made a phylogenetic analysis of the Cuban species using mitochondrial and nuclear genes finding several new evolutionary lineages not identified previously by morphological analyses. It was also indicated that the separation in Cuban and Bahamian species as suggested by Møller et al. (2006) is no longer correct, since some of the new Cuban species are more closely related to Bahamian species than to other Cuban species. Their results also questioned the specific status of Lucifuga teresinarum Diaz, 1988, showing no difference to L. subterranea Poey, 1858 (see also Lara et al. 2010).

A controversial taxon has been Lucifuga dentatus var. holguinensis Díaz-Pérez, Nieto and Abio, 1987 from the Holguin province in eastern Cuba. It was suggested as a valid species name by Proudlove (2019), but the name has now been decided to be infrasubspecific and unavailable according to ICZN Art. 15.2, since it was introduced as a variety after 1960 (Fricke et al. 2019). In the present study, based on the molecular results of García-Machado et al. (2011) and from revisiting the morphological characters recently used to define species in the genus (Møller et al. 2006), we present a new formal description of the species as Lucifuga gibarensis sp. nov.

\section{Materials and methods}

The morphological study of the Cuban Lucifuga species was based on the analysis of 214 individuals sampled from several localities covering most of its known distribu- 
tion areas (Fig. 1). Nine morphometric measurements were taken using a Vernier calliper (precision $0.05 \mathrm{~mm}$ ) and eleven meristic counts (e.g., fin ray numbers, scales, etc.) were carried out using a Novel stereomicroscope (magnification $40 \mathrm{x}$ maximum) and/ or radiographs. All morphometric measurements were weighted according to the standard length (SL) to avoid allometric effects. The number of vertebrae was counted using X-ray radiographs.

Abbreviations include:

ANSP Academy of Natural Sciences of Drexel University, Philadelphia, Pennsylvania, U.S.A;

FMNH Division of Fishes, Department of Zoology, Field Museum of Natural History, Chicago, Illinois, U.S.A.;

MCZ Museum of Comparative Zoology, Harvard University, Ichthyology Department, Cambridge, Massachusetts, U.S.A;

MFP Felipe Poey Museum of Havana University, Cuba;

UMMZ University of Michigan Museum of Zoology, Ann Arbor, Michigan, U.S.A.;

ZMB Museum für Naturkunde, Leibniz-Institut für Evolutions- und Biodiversitätsforschung, Berlin, Germany;

ZMUC Natural History Museum of Denmark, University of Copenhagen, Denmark.

\section{Taxomomy}

\section{Family Bythitidae}

\section{Genus Lucifuga Poey, 1858}

Type species. Lucifuga subterranea Poey, 1858 by subsequent designation of Jordan and Evermann, 1896, type locality: El Cajio cave, but not precisely stated for L. subterranea, which was referred originally from caves of San Antonio, middle-south Havana province, Cuba.

Diagnosis. Body moderately elongated and compressed mainly from the abdomen to the caudal end. Snout with two nostrils: anterior nostril tube-shape and smaller, placed near to the upper lip; posterior nostril is a larger hole, placed ca. midway between snout and eyes cavity. The mouth is subterminal with the lower jaw only slightly shorter than the upper. Opercular spines absent. Seven branchiostegal rays.

The entire body is covered with small, rounded cycloid scales; fins naked except for scales on pectoral fin basis. Predorsal area and operculum scaled. Branchiostegal membranes, entire underside of the head, snout, interorbital areas and entire course of the cavernous cephalic system are naked. Origin of dorsal fin approximately above the tip of pectoral fins. Pelvic fin is subjugular with a single ray reaching ca. 1/3 to halfway to the anus. Pectoral fin behind the operculum, peduncle short and narrow. Lateral line 
with two series of sensory neuromasts: upper and anterior series extends from the head to a point ca. midway between dorsal and anal fin origins; and lower and posterior series extends from a point under and slightly in advance of the end of the upper series to the mid side from the caudal base.

There are three symmetric sensory canal series on each side of the head: supraorbital series with three pores (two anterior and one posterior): the anteriormost is at the snout rim, the second open between and above the nasal openings, and the posterior single pore is at the end of the lateral canal above the operculum. The infraorbital series with six pores (three anterior and three posterior): first pore is slightly below the anterior nasal opening, the other five pores (two anterior and three posterior) are along the edge of infraorbital rim. Finally, the mandibular series with six pores (three anterior and three posterior). The first pore is in the fold of skin between the lip and canal series, the second is at the side of the jaw tip on the lower lip, the third is at the anterior end of the mandibular series, the fourth to sixth posterior pores open ventrally along the mandibular series. There is also a large preopercular pore. Teeth are present on the premaxillae, dentaries and vomer; but are present or absent in palatines.

Sexual dimorphism. The male copulatory organ is completely integrated into a fleshy genital hood which projects posteriorly beyond the anus, the lateral end of the hood could be from broad to conical. A fleshy small conical papillae project from the middle of the distal margin of the hood and is enclosed by lateral earlike lobes. Penis is placed underneath the hood.

\section{Lucifuga gibarensis sp. nov.}

http://zoobank.org/4D8B142C-4CAE-49CB-B93D-42FA40B266A9

Figures 1-3; Tables 1, 2

Common name: Gibara cave brotula (English)

Lucifuga dentatus variety holguinensis Díaz-Pérez et al., 1987b: 44 .

Lucifuga dentatus var. holguinensis Hernández 2005: 15; García-Machado et al. 2011: 471. Lucifuga holguinensis Proudlove 2019.

Holotype. MFP 18.000420, $89.3 \mathrm{~mm}$ SL, female, Aguada de Macigo cave, ca. $21^{\circ} 09^{\prime} 42^{\prime \prime} \mathrm{N}, 76^{\circ} 14^{\prime} 55^{\prime \prime W}$, near Gibara municipality, Northern Holguin province, Cuba, collected by Eduardo Nieto, in 1986, designated as Lucifuga dentatus variety holguinensis by Díaz-Pérez et al. (1987b).

Paratypes. MFP 18.000399, $69.3 \mathrm{~mm} \mathrm{SL}$, male, Tanque Azul cave, ca. $21^{\circ} 12^{\prime} 6 " \mathrm{~N}$, $76^{\circ} 13^{\prime} 59^{\prime \prime W}$, near Gibara municipality, Northern Holguin province, Cuba, collected by Alfredo García-Debrás, 2 June 1997; MFP 18.000278, 89.2 mm SL, male, Aguada de Macigo cave, Gibara municipality, Northern Holguin province, Cuba, collected by Arturo Rojas, 21 November 2014; ZMUC P771732, 45.0 mm SL, male, Cueva El Baga, ca. $21^{\circ} 11^{\prime} 51^{\prime \prime} \mathrm{N}, 76^{\circ} 14^{\prime} 3^{\prime \prime} \mathrm{W}$, near Gibara municipality, northern Holguin province, Cuba, collected by Katrine Worsaae and Peter Rask Møller, 27 November 2014. 
Diagnosis. Dorsal fin rays 72-90; anal fin rays 58-72; pectoral fin rays 15-17, caudal fin rays 10; palatine teeth absent; rakers on anterior gill arch 17-19 (long gillrakers 3); occiput and area between lateral canal and preopercular canal scaled; diameter of pigmented eyes 1.1-1.9\% SL; total vertebrae 50-53.

Description. Meristic and morphometric characters are given in Tables 1, 2. Body moderately elevated behind the head, with a slight depression in the interorbital region (Figs 2, 3). Eyes pigmented (similar to the condition present in L. spelaeotes and $L$. lucayana (Møller et al. 2006)). Anterior gill arch with three elongate rakers and 14-16 low dentigerous pads. The areas between lateral canal and preopercular canal, and the occiput are scaled (Fig. 2). Caudal fin free (not fused with dorsal and anal fins). In the lateral line series of sensory neuromasts, the upper and anterior count with 13-15, the lower and posterior with 30-35. Teeth are present on the premaxillae (5-7 rows), dentaries (6 or 7 rows) and vomer ( 2 or 3 rows in two separate patches). Palatines without teeth.

Coloration. Uniformly brown or light brown, with lighter fins and naked parts on the head. Nevertheless, one juvenile specimen (ZMUC P771732) was very pale, but still with tiny dark pigment dots (Fig. 3b).

Distribution and habitat. Lucifuga gibarensis shows a very restricted known distribution, in a lithographically isolate karst patch of caves at the north of Gibara municipality, Holguín province, without any overlap with other Cuban species of the genus (Fig 1; García-Machado et al. 2011; Hernández et al. 2016). It is ca. $800 \mathrm{~km}$ away from the nearest $L$. dentata, $L$. subterranea and $L$. simile distribution areas. The distance to the Bahamian species on Little Bahama Bank (L. lucayana) and Great Bahama Bank (L. spelaeotes) is ca. $650 \mathrm{~km}$ and $240 \mathrm{~km}$, respectively. The location area is composed by three caves (Aguada de Macigo, Tanque Azul and Cueva El Baga) located near to the shore ca. 3-15 km from each other (Corella et al. 2000, Dietz 2015). The Aguada de Macigo cave is the type-locality with an emergent large doline, ca. $22 \mathrm{~m}$ deep and salinity of 16 ppt. According to Díaz-Pérez et al. (1987b), the individual designated as holotype was caught at $12 \mathrm{~m}$ depth.

Etymology. The specific epithet refers to the village of Gibara, where the three caves inhabited by this species are located. We do not follow variety epithet used by Díaz-Pérez et al. (1987b), since the L. gibarensis better describes the narrow distribution of the species near the village Gibara instead of the entire region Holguin.

Genetic distances. Among Cuban species, García-Machado et al. (2011) have demonstrated that $L$. gibarensis [at that time as $L$. dentata var. holguinensis] is not phylogenetically close to $L$. dentata by showing a large mitochondrial DNA divergence of $30.5 \%$ (16.5\% with cytochrome $b$ gene) as well as several diagnostic nucleotide variations at nuclear genes. In contrast, $L$. gibarensis is phylogenetically closely related to other two lineages of undescribed species of Lucifuga from Cuba (named Lucifuga sp. 3 and L. sp. 4) (García-Machado et al. 2011). However, genetic distance to both Bahamian species is not yet known.

Comparisons. Based on external appearance, Lucifuga gibarensis sp. nov. resembles the Cuban species $L$. dentata (from which it was designated as variety, see Díaz et al. 


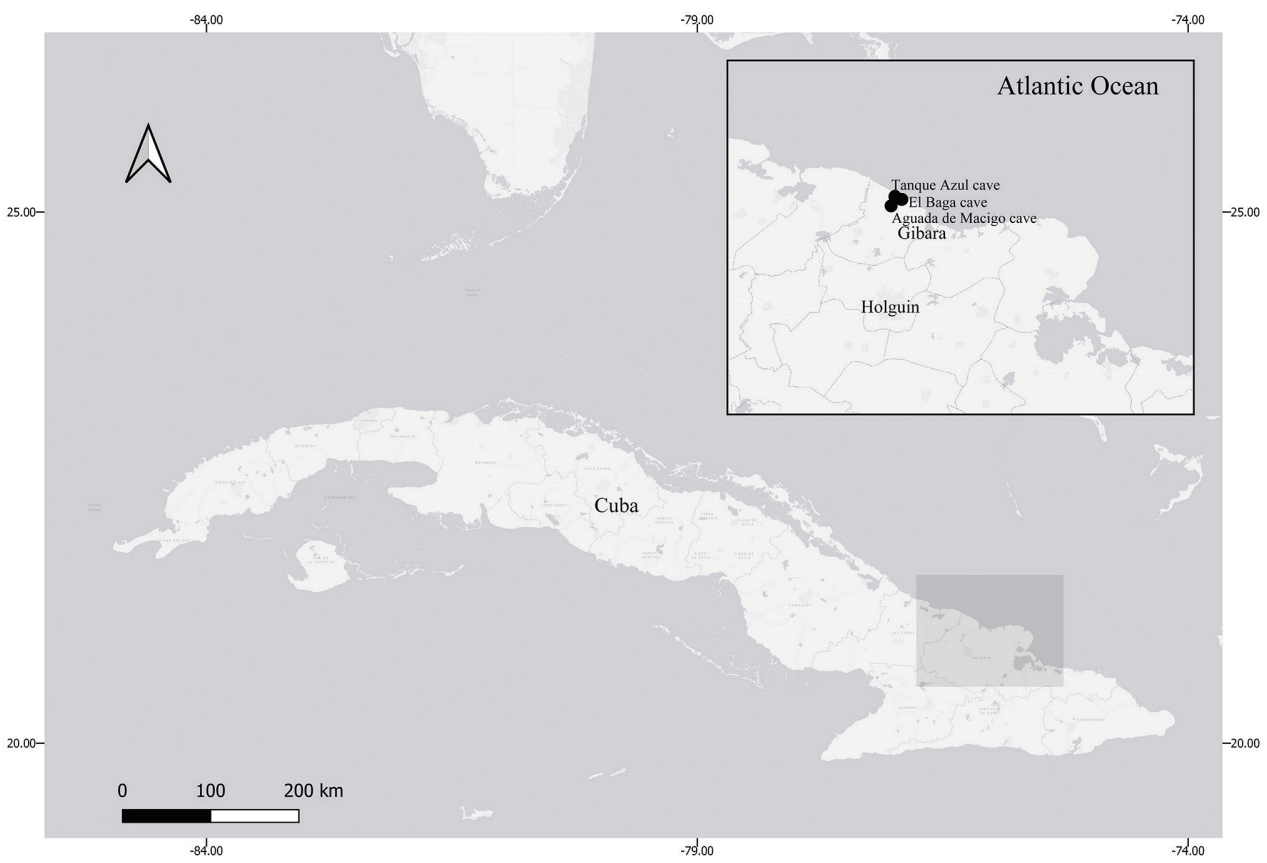

Figure I. Sample sites of Lucifuga gibarensis sp. nov. in eastern Cuba.

1987b) and L. simile. Nonetheless, it differs in several characters: e.g., number of caudal fin rays ( 10 vs. 8 ), diameter of the pigmented eyes (1.1-1.9 vs. $0.0-0.2 \% \mathrm{SL}$ ), lack of palatine teeth vs. present and scaled occiput vs. naked or weakly scaled occiput. It also differs in dorsal and anal fin rays mean number (fewer than L. dentata and more than L. simile) (Table 1).

Lucifuga gibarensis sp. nov. also resembles L. subterranea in the lack of palatine teeth and the scaled occiput, but it differs in the body moderately elevate behind the head vs. little elevated (see maximum height in Table 1), number of pectoral fin rays (15-17 vs. 10-13), number of caudal fin rays (10 vs. 8), the diameter of the pigmented eyes (1.1-1.9 vs. $0.0-0.3 \% \mathrm{SL})$ and in the number of rakers on the anterior gill arch 17-19 vs. $12-17$ (Table 1$)$.

Finally, Lucifuga gibarensis resembles both Bahamian species in the head profile, the number of caudal fin rays (10), the occiput scales (similar to L. spelaeotes and less scaled than L. lucayana) and in the presence of relatively large pigmented eyes (Table 1). With L. lucayana it also shares the lack of palatine teeth. It differs in the number of pectoral fin rays (15-17 vs. 17-18 in L. lucayana and 17-20 in L. spelaeotes); and diameter of pigmented eye is larger than in $L$. lucayana (1.1-1.9 vs. $0.9-1.0 \% \mathrm{SL}$ ).

Remarks. It has been demonstrated that L. gibarensis is not phylogenetically close to $L$. dentata. The estimate of mtDNA genetic divergence between these two lineages is huge $(\mathrm{P}=30.5 \%)$ and several diagnostic nucleotide changes at the intron 4 of calmoduline gene and intron 1 of the homeodomain EVX gene were described 


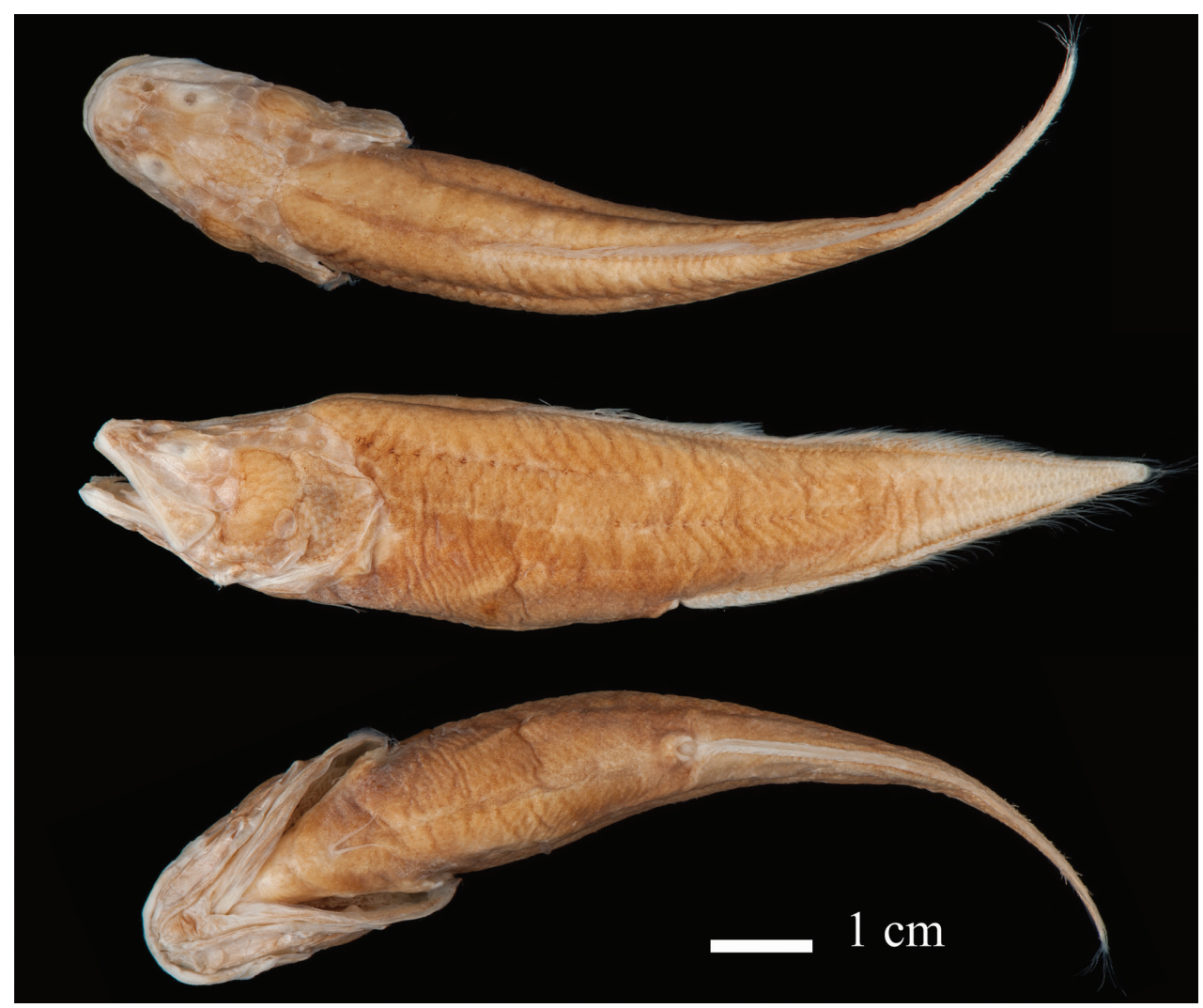

Figure 2. Lucifuga gibarensis sp. nov. Holotype, MFP 18.000420, $89.3 \mathrm{~mm} \mathrm{SL}$, female, Aguada de Macigo cave, Gibara municipality, Northern Holguin province, Cuba.

(García-Machado et al. 2011). Designation as a variety of L. dentata, was wrong as judgment, given the sharp differences observed at three major morphological characters: palatine teeth; number of caudal fin rays; and degree of pigmentation in the eyes. Particularly, the number of caudal fin rays (10) and pigmented eyes were realised in $L$. spelaeotes description (Cohen and Robins 1970), and recognised as diagnostic characters to distinguish the Cuban and Bahamian species at that time (Cohen and Robins 1970; Møller et al. 2006).

As a result of the present study, we describe a new species, Lucifuga gibarensis, which is supported by morphology and molecular phylogenetic analysis (García-Machado et al. 2011). We found unique diagnostic characters that distinguish this species from all the species described so far. Díaz-Pérez et al. (1987b) identified this taxon as a variety of Lucifuga dentata (L. dentata var. holguinensis), and recognised the presence of 10 caudal fin rays and pigmented eyes (characters distinguished by Cohen and Robins (1970) as important to separate L. spelaeotes from the two Cuban species known at that time), but underestimated the taxonomic relevance of these characters and avoid them. They also underrated the absence of palatine teeth vs. present in L. dentata, a 

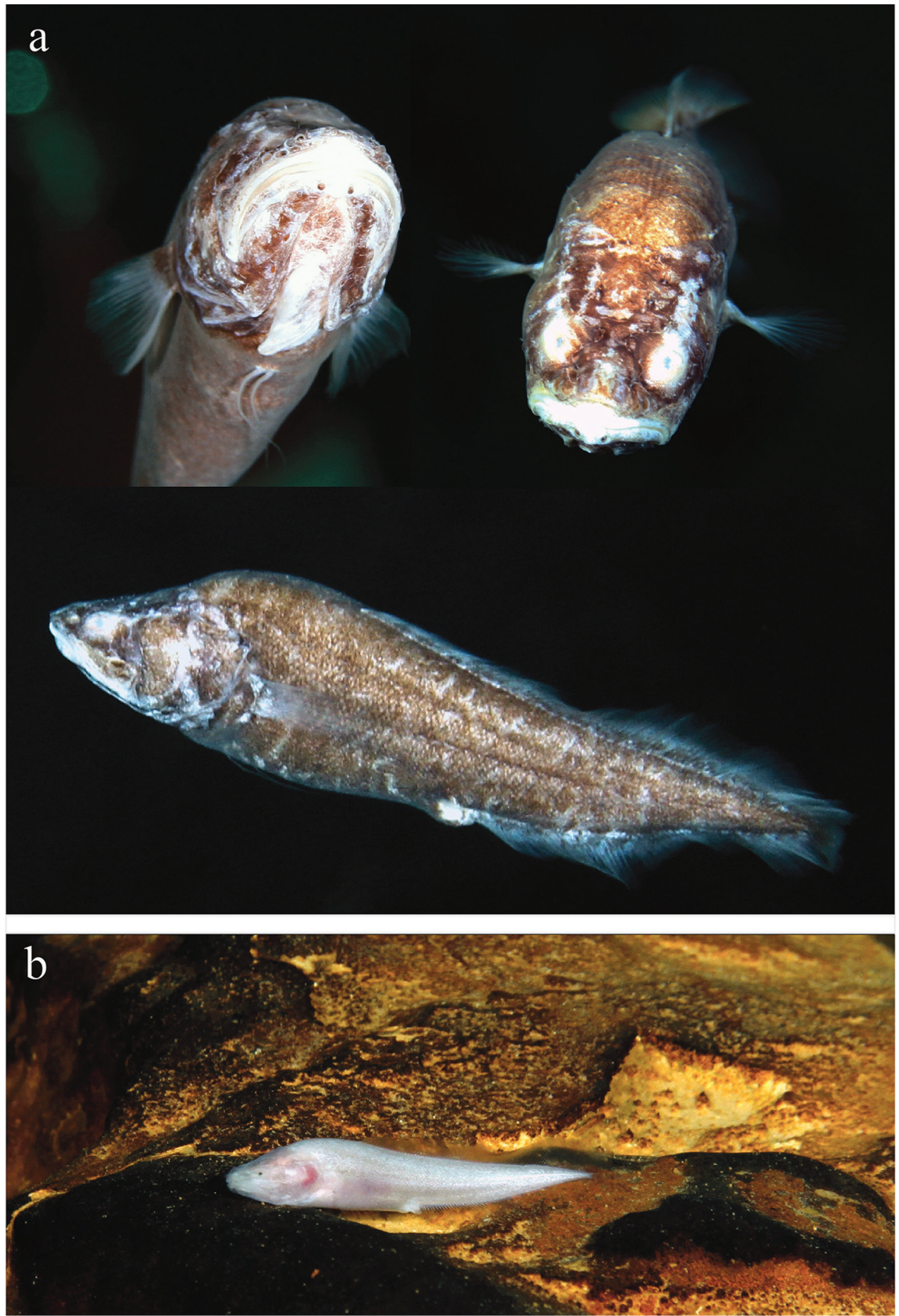

Figure 3. Lucifuga gibarensis sp. nov. in Cueva El Baga, Gibara municipality, northern Holguin province, Cuba, a unsampled specimen, 27 November 2014 b ZMUC P771732, 45.0 mm SL, male, photo taken immediately prior to collection. 


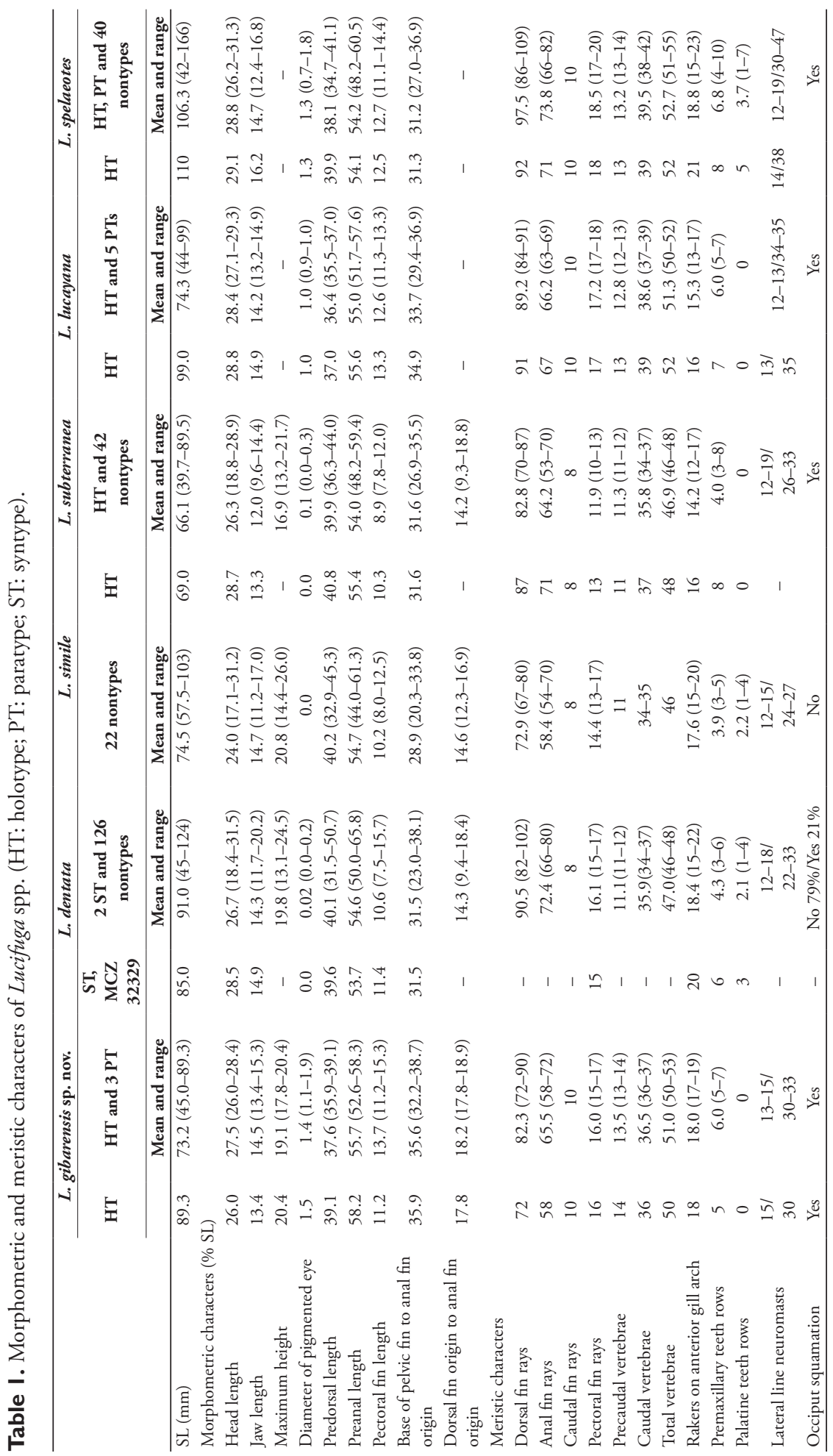


Table 2. Frequency of meristic characters in Lucifuga spp.

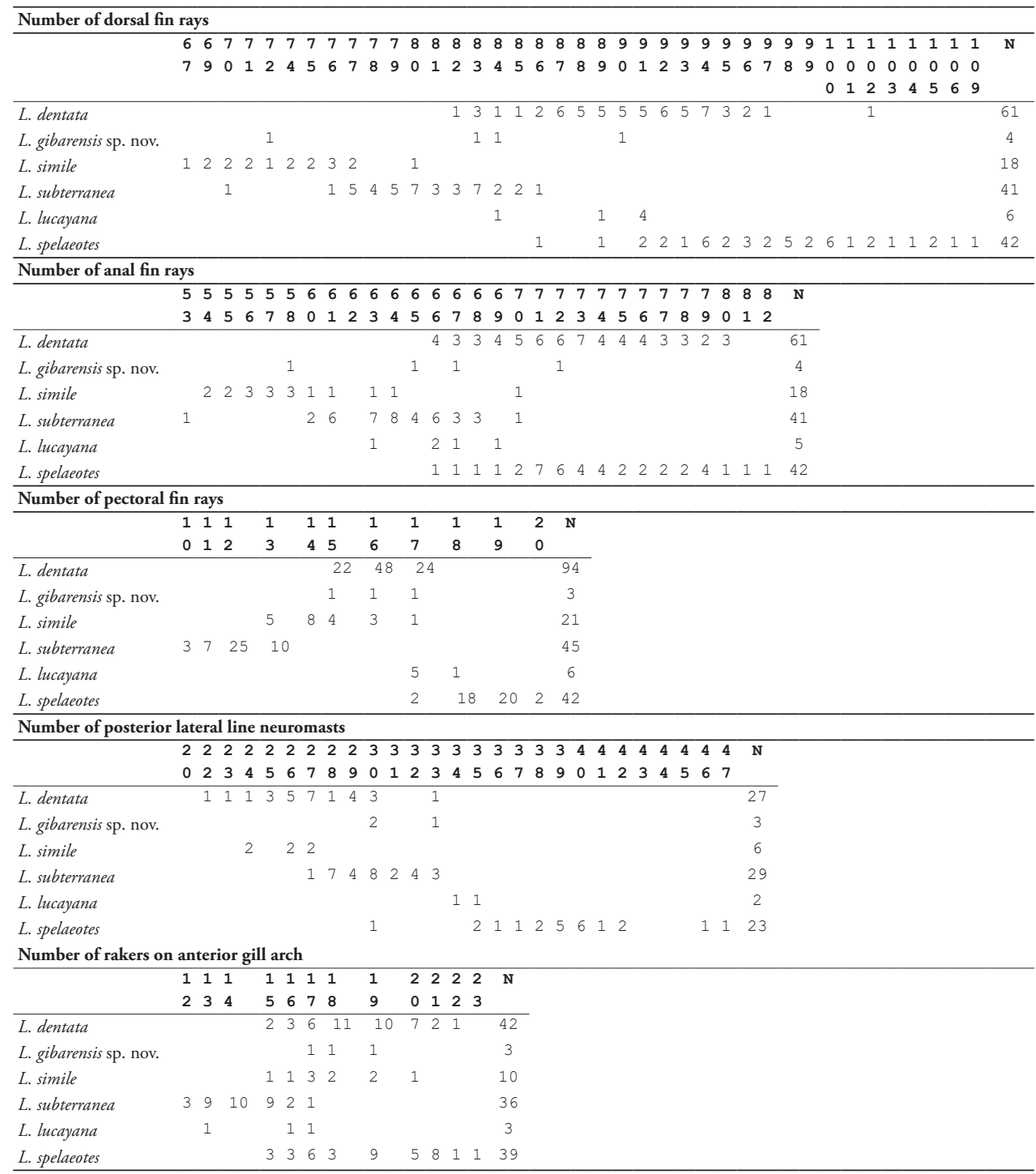

useful taxonomic character to distinguish Lucifuga species (see Poey 1858; Møller et al. 2006). Furthermore, Møller et al. (2006) pointing out that the Bahamian species differing from all four Cuban species formerly known by having higher caudal fin rays number (10 vs. 8 ), larger pigmented eyes diameter (0.7-1.8 vs. $0.0-0.3 \%$ SL), higher vertebrae number (50-55 vs. $45-48)$, and higher pectoral fin rays number (17-20 vs. 10-17) supporting the hypothesis that Bahamas and Cuba are represented by two different evolutionary lineages (see also Vergara 1980, 1981). However, the new Cuban species L. gibarensis, shared a similar combination of these characters with Bahamian 
species apart from low number of pectoral fin rays in L. gibarensis. Based on these characters, our results do not support that lineages are confined to only one Archipelago. With the available knowledge, species with reduced or completely absence of eyes and 8 fin rays are only found in western Cuba; but species having pigmented eyes and 10 caudal fin rays are found in both archipelagos. Detailed phylogenetic studies including all Atlantic Lucifuga spp. will be crucial to clarify the phylogeographic relationships between the Cuban and Bahamian members of this genus.

\section{Identification key to species of Lucifuga}

The current key is based on a small number of samples. Measures that overlapping in range were only used when it helps distinguishing between two species.

1 Diameter of pigmented eyes $0.0-0.3 \%$ SL, caudal fin rays 8 , number of ver-

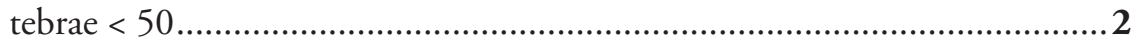

- $\quad$ Diameter of pigmented eyes $>0.7 \%$ SL, caudal fin rays 10 , number of verte-

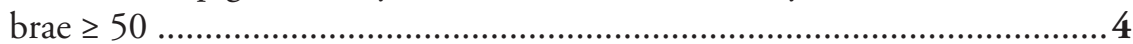

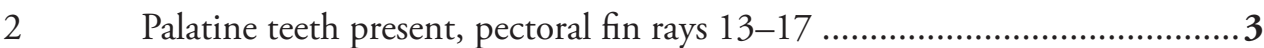

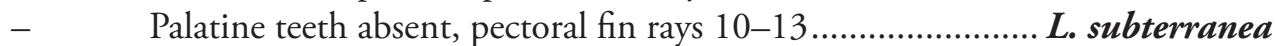

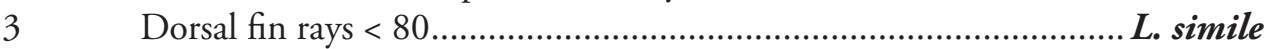

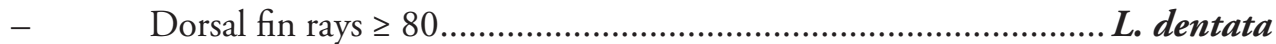

$4 \quad$ Palatine teeth present, lateral occipital area naked ..................... L. spelaeotes

- $\quad$ Palatine teeth absent, lateral occipital area scaled.........................................5

5 Pigmented eye diameter $0.9-1.0 \%$ SL, number of posterior lateral line neu-

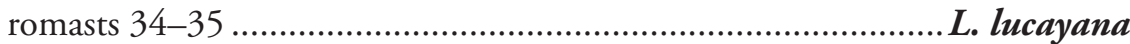

- $\quad$ Pigmented eye diameter 1.1-1.9\% SL, number of posterior lateral line neu-

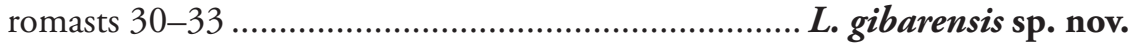

\section{Comparative material}

\section{Lucifuga subterranea Poey, 1858}

Material examined. (38 specimens: 18 females, 20 males).

Holotype: ZMB 6314, 69 mm SL, female, Cueva de Cajio, potrero de Torres, dos leguas, Sur de Guira de Melena, Habana province, Cuba, collected by Felipe Poey (see discussion about type status in Proudlove (2019)).

Additional specimens. ANSP 37111, $70 \mathrm{~mm}$ SL, female, Canas, Cuba, collected by C.H. Eigenmann, exact location unknown, 10 March 1903; FMNH 3934, 67 mm SL, male, Canas Cuba, exact location and date unknown; FMNH 33090-91, 67$74 \mathrm{~mm}$ SL, females, Cuba, exact location and date unknown; FMNH 52631, $77 \mathrm{~mm}$ SL, male, $80 \mathrm{~mm}$ SL, female, Cuba, exact location and date unknown; MFP 18.000199, $39.7 \mathrm{~mm}$ SL, male, Paredones cave, La Salud locality, Caimito municipality, collected by Erik García-Machado, Pedro Chevalier and Damir Hernández, 18 March 2004; 
MFP 18.000371 (7 specimens), 41.45-67.5 mm SL, Juanelo Piedra cave, Quibicán municipality, collected by A. Sosa, date unknown; MFP 18.000372, $80.2 \mathrm{~mm} \mathrm{SL}$, male, Juanelo Piedra cave, Quibicán municipality, collected by Erik García-Machado, Pedro Chevalier and Damir Hernández, 1 July 2005; MFP 18.000373, 76.2 mm SL female, Juanelo Piedra cave, Quibicán municipality, collected by Erik García-Machado, Pedro Chevalier and Damir Hernández, 1 July 2005; MFP 18.000374, 71.85 mm SL male, Juanelo Piedra cave, Quibicán municipality, collected by Erik García-Machado, Pedro Chevalier and Damir Hernández, 1 July 2005; MFP 18.000198, 74.55 mm SL, male, Juanelo Piedra cave, Quibicán municipality, collected by Erik García-Machado, Pedro Chevalier and Damir Hernández, 1 July 2005; MFP 18.000375 (10 specimens), 27.65-75.6 mm SL, Luis Piedra cave, Quibicán municipality, collected by Alfredo Garcia-Debrás, July 1993; MFP 18.000376 (2 specimens), 52.0-79.4 mm SL, Emilio cave, Ashton formation, Las Cañas locality, Artemisa municipality, collected by Antonio Nuñez Jimenez, 7 November 1943; MFP 18.000377 (4 specimens), 70.5$89.55 \mathrm{~mm}$ SL, Emilio cave, Ashton formation, Las Cañas locality, Artemisa municipality, collected by Armando Montoto and Gonzalo Abio, 5 May 1984; MFP 18.000378, $75.0 \mathrm{~mm}$ SL, male, Emilio cave, Ashton formation, Las Cañas locality, Artemisa municipality, collected by Erik García-Machado, Pedro Chevalier, Armando Montoto and Lisset Gómez, 25 October 2000; MFP 18.000379, 78.25 mm SL, female, Emilio cave, Ashton formation, Las Cañas locality, Artemisa municipality, collected by Erik GarcíaMachado, Damir Hernández and Didier Casane, 15 December 2008; MFP 18.000380 (3 specimens), 47.3-78.1 mm SL, Baño II cave, Ashton formation, Las Cañas locality, Artemisa municipality, collected by Gonzalo Abio, Erik García-Machado and Armando Montoto, 20 October 1984; MFP 18.000381, 60.25mm SL, female, Baño II cave, Ashton formation, Las Cańas locality, Artemisa municipality, collected by Erik García-Machado, Pedro Chevalier and Damir Hernández, 25 September 2005; MFP 18.000382, $62.3 \mathrm{~mm}$ SL, male, Baño II cave, Ashton formation, Las Cañas locality, Artemisa municipality, collected by Erik García-Machado, Pedro Chevalier and Damir Hernández, 25 September 2005; MFP 18.00038368 .7 mm SL, male, Baño II cave, Ashton formation, Las Cañas locality, Artemisa municipality, collected by Erik GarcíaMachado, Pedro Chevalier, Armando Montoto and Lisset Gómez, 25 October 2000; MFP 18.000200, $69.3 \mathrm{~mm}$ SL, female, Lechuza cave, Ashton formation, Las Cañas locality, Artemisa municipality, collected by Erik García-Machado, Pedro Chevalier and Damir Hernández, 7 November 2002; MFP 18.000384, 62.0 mm SL, female, El Sitio cave, Ashton formation, Las Cañas locality, Artemisa municipality, collected by José Martínez and Gonzalo Abio, 20 October 1984; MFP 18.000385 (Holotype of Lucifuga teresinarum) $71.9 \mathrm{~mm}$ SL, male, Lechuza cave, Ashton formation, Las Cañas locality, Artemisa municipality, collected by Erik García-Machado and Armando Montoto, 20 October 1986; MFP 18.000386 (Paratype of Lucifuga teresinarum) $78.5 \mathrm{~mm}$ SL, male, Baño II cave, Ashton formation, Las Cañas locality, Artemisa municipality, collected by Erik García-Machado and Armando Montoto, 20 October 1986; MFP 18.000387, 77.3 mm SL, female, Baño II cave, Ashton formation, Las Cańas locality, Artemisa municipality, collected by Erik García-Machado, Pedro Chevalier and 
Damir Hernández, 7 November 2002; MFP 18.000388, 57.3 mm SL, female, Baño II cave, Ashton formation, Las Cañas locality, Artemisa municipality, collected by Erik García-Machado, Pedro Chevalier and Damir Hernández, 7 November 2002; UMMZ 157178 (5 specimens), 52-60 mm SL, Cuba, no further data.

Remarks. Díaz-Pérez (1988) distinguished L. teresinarum from L. subterranea by the relationships among the dorsal, anal and caudal fins (i.e., independent in the first vs. broadly joined in the second), as well as by the shape of the hood of the male copulatory organ (i.e., broad distal lateral ends in L. teresinarum vs. conical in L. subterranea); and pointed out that $L$. teresinarum shares both characters states with $L$. dentata. Evidence from molecular data (García-Machado et al. 2011) and morphological considerations indicate that this species is invalid and will be regarded as a synonymy of L. subterranea. All measures from the four specimens examined were included within L. subterranea. Previous descriptions have indicated that L. subterranea has a caudal fin broadly joined to dorsal and anal fins (Poey 1858; Cohen and Robins 1970; Nalbant 1981; Nielsen et al. 1999; Møller et al. 2006). However, as noticed previously by García-Machado et al. (2011) four individuals collected at Baño II cave have the caudal fin joined to the anal but free from the dorsal, a variant previously observed in $L$. simile (Díaz-Pérez et al. 1987a; Díaz-Pérez 1988). The redefinition of L. teresinarum as a synonymy of $L$. subterranea increase the morphological variation in this species, only paralleled by L. simile (Díaz-Pérez et al. 1987a).

\section{Lucifuga dentata Poey, 1858}

Material examined. (126 specimens: 63 females, 63 males).

Syntypes and/or Poey specimens. MCZ 12415, 32329, 85-90 mm SL, females, Cave of Cajio, Cuba.

Additional specimens. MFP 18.000312, $93.6 \mathrm{~mm}$ SL, female, El Judio cave, Guanahacabibes peninsula, Sandino municipality, collected by José Luis Ponce de León, October 2006; MFP 18.000048, 97.35 mm SL, female, El Judio cave, Guanahacabibes peninsula, Sandino municipality, collected by José Luis Ponce de León, October 2006; MFP 18.000195, 107.1 mm SL, male, El Judio cave, Guanahacabibes peninsula, Sandino municipality, collected by Niurka Hernández, 11 September 2006; MFP $18.000313100 .1 \mathrm{~mm}$ SL, female, El Judio cave, Guanahacabibes peninsula, Sandino municipality, collected by José Ponce de León, April 2007; MFP 18.000314 $95.1 \mathrm{~mm}$ SL, female, El Judio cave, Guanahacabibes peninsula, Sandino municipality, collected by José Ponce de León, April 2007; MFP 18.000315 78.5 mm SL, female, El Judio cave, Guanahacabibes peninsula, Sandino municipality, collected by José Ponce de León, April 2007; MFP 18.000316, 79.95 mm SL, female, El Grillo cave, El Valle locality, Sandino municipality, collected by Yosvani Medina and Damir Hernández, 7 May 2003; MFP 18.000317 (2 specimens), 75.95-100.9 mm SL, La Raja cave, La Jarreta locality, Sandino municipality, collected by Yosvani Medina and Damir Hernández, 6 May 2003; MFP 18.000318 (3 specimens), 93.0-93.5 mm SL, El Jagüey cave, 
Majin locality, Sandino municipality, collected by Yosvani Medina and Damir Hernández, 30 April 2003; MFP 18.000319 (3 specimens), 75.6-104.3 mm SL, El Patrón cave, Majin locality, Sandino municipality, collected by Yosvani Medina and Damir Hernández, 30 April 2003; MFP 18.000320 (4 specimens), 77.25-97.25 mm SL, Felipe cave, Cayuco locality, Sandino municipality, collected by Erik García-Machado and Pedro Chevalier, 1 March 2001; MFP 18.000321, 81.05 mm SL, female, Pozo Azul sinkhole, Cayuco locality, Sandino municipality, collected by Erik García-Machado, Pedro Chevalier and Damir Hernández, 18 September 2007; MFP 18.000322, $92.5 \mathrm{~mm}$ SL, female, Pozo Azul sinkhole, Cayuco locality, Sandino municipality, collected by Erik García-Machado, Pedro Chevalier and Damir Hernández, 18 September 2007; MFP 18.000323, 90.15 mm SL, male, Pozo Azul sinkhole, Cayuco locality, Sandino municipality, collected by Erik García-Machado, Pedro Chevalier and Damir Hernández, 18 September 2007; MFP 18.000324, 82.9 mm SL, female, Pozo Azul sinkhole, Cayuco locality, Sandino municipality, collected by Erik García-Machado, Pedro Chevalier and Damir Hernández, 18 September 2007. South of Havana Province: MFP 18.000325 (2 specimens), 100.0-103.4 mm SL, Paredones cave, La Salud locality, Caimito municipality, collected by Antonio Nuñez Jimenez, date unknown; MFP 18.000326, 105.0 mm SL, female, Paredones cave, La Salud locality, Caimito municipality, collected by José Álvarez Lemus, date unknown; MFP 18.000327, $52.5 \mathrm{~mm}$ SL, female, Paredones cave, La Salud locality, Caimito municipality, collected by Erik García-Machado, Pedro Chevalier and Damir Hernández, 18 March 2004; MFP 18.000328, 82.55 mm SL, female, Paredones cave, La Salud locality, Caimito municipality, collected by Erik García-Machado, Pedro Chevalier and Damir Hernández, 18 March 2004; MFP 18.000329, 86.61 mm SL, female, Paredones cave, La Salud locality, Caimito municipality, collected by Erik García-Machado, Pedro Chevalier and Damir Hernández, 18 March 2004; MFP 18.000330, 104.0 mm SL, male, Paredones cave, La Salud locality, Caimito municipality, collected by Erik GarcíaMachado, Pedro Chevalier and Damir Hernández, 18 March 2004; MFP 18.000331, $103.5 \mathrm{~mm}$ SL, male, Juanelo Piedra cave, Quibicán municipality, collected by José R. Martínez and Gonzalo Abio, date unknown; MFP 18.000332, $120.0 \mathrm{~mm}$ SL, male, Juanelo Piedra cave, Quibicán municipality, collected by Erik García-Machado, Pedro Chevalier and Damir Hernández, 1 July 2005; MFP 18.000333, 102.15 mm SL, male, Juanelo Piedra cave, Quibicán municipality, collected by Erik García-Machado, Pedro Chevalier and Damir Hernández, 1 July 2005; MFP 18.000334, 97.4 mm SL, male, Juanelo Piedra cave, Quibicán municipality, collected by Erik García-Machado, Pedro Chevalier and Damir Hernández, 1 July 2005; MFP 18.000335, 92.5 mm SL, male, Juanelo Piedra cave, Quibicán municipality, collected by Erik García-Machado, Pedro Chevalier and Damir Hernández, 1 July 2005; MFP 18.000336, 90.9 mm SL, female, Juanelo Piedra cave, Quibicán municipality, collected by Erik García-Machado, Pedro Chevalier and Damir Hernández, 1 July 2005; MFP 18.000368 (20 specimens), 75.9-121.2 mm SL, Luis Piedra cave, Quibicán municipality, collected by Alfredo Garcia-Debrás and Abel Ramirez, July 1993; MFP 18.000337119 .0 mm SL, male, Emilio cave, Ashton formation, Las Cañas locality, Artemisa municipality, col- 
lected by Erik García-Machado, 20 October 1984; MFP 18.000338, 115.0 mm SL, male, Emilio cave, Ashton formation, Las Cañas locality, Artemisa municipality, collected by Armando Montoto, Javier Vazquez, Erik García-Machado and Pedro A. Díaz, 26 January 1985; MFP 18.000339 (2 specimens), 96.0-99.1 mm SL, Emilio cave, Ashton formation, Las Cañas locality, Artemisa municipality, collected by Armando Montoto and Gonzalo Abio, 5 May 1984; MFP 18.000340 (4 specimens), 84.5-101.9 mm SL, Emilio cave, Ashton formation, Las Cañas locality, Artemisa municipality, collected by Erik García-Machado, Pedro Chevalier, Armando Montoto and Lisset Gómez, 25 October 2000; MFP 18.000342, 86.1 mm SL, male, Baño II cave, Ashton formation, Las Cañas locality, Artemisa municipality, collected by Gonzalo Abio, 20 October 1984; MFP 18.000343 (4 specimens), 67.15-90.25 mm SL, Baño II cave, Ashton formation, Las Cañas locality, Artemisa municipality, collected by Erik GarcíaMachado, Pedro Chevalier, Armando Montoto and Lisset Gómez, 25 October 2000; MFP 18.000196, 82.15 mm SL, female, Baño II cave, Ashton formation, Las Cañas locality, Artemisa municipality, collected by Erik García-Machado, Pedro Chevalier and Damir Hernández, 11 July 2002; MFP 18.000341 (2 specimens), 67.1590.25 mm SL, Baño II cave, Ashton formation, Las Cañas locality, Artemisa municipality, collected by Erik García-Machado, Pedro Chevalier and Damir Hernández, 11 July 2002; MFP 18.000345 (5 specimens), 74.3-95.25 mm SL, Lechuza cave, Ashton formation, Las Cañas locality, Artemisa municipality, collected by Erik García-Machado, Pedro Chevalier, Armando Montoto and Lisset Gómez, 25 October 2000; MFP 18.000344, $81.0 \mathrm{~mm}$ SL, female, El Sitio cave, Ashton formation, Las Cañas locality, Artemisa municipality, collected by José R. Martínez and Gonzalo Abio, 20 October 1984; MFP 18.000346, 85.0 mm SL, male, El Sitio cave, Ashton formation, Las Cañas locality, Artemisa municipality (collection data unknown). South of Matanzas Province: MFP 18.000347, 81.5 mm SL, male, Chicharrones cave, Bolondrón municipality, collected by Erik García-Machado, Pedro Chevalier and Damir Hernández, 28 April 2005; MFP 18.000348, 78.35 mm SL, male, Chicharrones cave, Bolondrón municipality, collected by Erik García-Machado, Pedro Chevalier and Damir Hernández, 28 April 2005; MFP 18.000349, 73.1 mm SL, female, Chicharrones cave, Bolondrón municipality, collected by Erik García-Machado, Pedro Chevalier and Damir Hernández, 28 April 2005; MFP 18.000350, 74.1 mm SL, female, Chicharrones cave, Bolondrón municipality, collected by Erik García-Machado, Pedro Chevalier and Damir Hernández, 28 April 2005; MFP 18.000351, 79.9 mm SL, female, Chicharrones cave, Bolondrón municipality, collected by Erik García-Machado, Pedro Chevalier and Damir Hernández, 28 April 2005; MFP 18.000352, 77.15 mm SL, male, Chicharrones cave, Bolondrón municipality, collected by Erik García-Machado, Pedro Chevalier and Damir Hernández, September 2008; MFP 18.000369 (11 specimens), 69.0-114.15 mm SL, Chicharrones cave, Bolondrón municipality, collected by Alfredo Garcia-Debrás, October 1996; MFP 18.000370 (3 specimens), 74.0-104.0 mm SL, Los Chivos cave, Bolondrón municipality, collected by Alfredo Garcia-Debrás, October 1996; MFP 18.000367 (12 specimens), 65.25-120.1 mm SL, Los Chivos cave, Bolondrón municipality, collected by Alfredo Garcia-Debrás, October 1996; 
MFP 18.000197, 78.95 mm SL, male, Perico Sánchez cave, Jagüey Grande municipality, collected by Erik García-Machado, Pedro Chevalier and Damir Hernández, 27 April 2005; MFP 18.000353, 69.05 mm SL, female, Perico Sánchez cave, Jagüey Grande municipality, collected by Erik García-Machado, Pedro Chevalier and Damir Hernández, 27 April 2005; MFP 18.000354, 67.45 mm SL, male, Perico Sánchez cave, Jagüey Grande municipality, collected by Erik García-Machado, Pedro Chevalier and Damir Hernández, 27 April 2005; MFP 18.000355, 71.55 mm SL, female, Perico Sánchez cave, Jagüey Grande municipality, collected by Erik García-Machado, Pedro Chevalier and Damir Hernández, 27 April 2005; MFP 18.000356, 72.9 mm SL, female, El Pozo cave, Agramonte municipality, collected by Erik García-Machado, Pedro Chevalier and Damir Hernández, 27 April 2005; MFP 18.000357, 72.95 mm SL, female, El Pozo cave, Agramonte municipality, collected by Erik García-Machado, Pedro Chevalier and Damir Hernández, 27 April 2005; MFP 18.000358, 79.5 mm SL, female, El Pozo cave, Agramonte municipality, collected by Erik García-Machado, Pedro Chevalier and Damir Hernández, 27 April 2005; MFP 18.000359, 66.95 mm SL, female, El Pozo cave, Agramonte municipality, collected by Erik García-Machado, Pedro Chevalier and Damir Hernández, 27 April 2005; MFP 18.000360, 87.05 mm SL, male, El Pozo cave, Agramonte municipality, collected by Erik García-Machado, Pedro Chevalier and Damir Hernández, 27 April 2005; MFP 18.000361, 82.6 mm SL, female, El Pozo cave, Agramonte municipality, collected by Erik García-Machado, Pedro Chevalier and Damir Hernández, 27 April 2005; MFP 18.000362, 114.15 mm SL, male, La Carreta cave, Agramonte municipality, collected by Erik García-Machado, Pedro Chevalier, Didier Casane and Damir Hernández, 26 July 2005; MFP 18.000363 , $91.6 \mathrm{~mm}$ SL, male, La Carreta cave, Agramonte municipality, collected by Erik GarcíaMachado, Pedro Chevalier, Didier Casane and Damir Hernández, 26 July 2005; MFP 18.000364, $106.9 \mathrm{~mm}$ SL, male, La Ratonera cave, Agramonte municipality, collected by Erik García-Machado, Pedro Chevalier, Didier Casane and Damir Hernández, 26 July 2005; MFP 18.000365, 105.2 mm SL, male, La Ratonera cave, Agramonte municipality, collected by Erik García-Machado, Pedro Chevalier, Didier Casane and Damir Hernández, 26 July 2005; MFP 18.000366, 99.2 mm SL, male, La Ratonera cave, Agramonte municipality, collected by Erik García-Machado, Pedro Chevalier, Didier Casane and Damir Hernández, 26 July 2005.

Remarks. Lucifuga dentata has been described as having the caudal fin free from dorsal and anal fins and the occiput naked (Poey, 1858; Cohen and Robins, 1970; Vergara, 1980; Nalbant, 1981; Nielsen et al., 1999; Møller et al. 2006). However, we have found that in $60 \%$ of the specimens the caudal fin is partially joined to the dorsal and anal fins by tiny basal membranes. Additionally, two individuals, from Luis Piedra caves, have the caudal fin broadly joined to the anal fin. These two conditions were previously assigned as diagnostic for L. simile (Díaz et al. 1987a; Díaz 1988). We also found that around $14 \%$ of the specimens have the occiput with different degrees of squamation as described for $L$. spelaeotes.

As mention previously for $L$. subterranea, the sampling at localities near to those mentioned in Poey's original description of the species, applied exactly for $L$. dentata. 
We also use several exemplars from Juanelo Piedra and Luis Piedra caves which are near to El Cajio cave (ca. $2 \mathrm{~km}$ ) the type-locality referred by Poey (1858). Lucifuga dentata is the most abundant and widely distributed Lucifuga species in Cuba. It is found in caves from median-southern karts from central (Matanzas province) to the western part of the island (Guanahacabibes Peninsula). Its distribution is not continuous, with the most important gap between western Havana and Guanahacabibes, Pinar del Río (Hernández et al. 2016).

\section{Lucifuga simile Nalbant, 1981}

Material examined. (22 specimens: 8 females, 14 males).

Additional specimens. MFP 18.000406, (4 specimens), 57.5-100.5 mm SL, Grieta Punta de Guana crevice, Matanzas municipality, North of Matanzas province, Cuba, collected by Gonzalo Abio, Armando Montoto and Erik García-Machado, 6 October 1984; MFP 18.000407, 62.55 mm SL, male, Grieta Punta de Guana crevice, Matanzas municipality, North of Matanzas province, Cuba, collected by Gonzalo Abio, November 1984; MFP 18.000408, 66.65 mm SL, female, Grieta Punta de Guana crevice, Matanzas municipality, North of Matanzas province, Cuba, collected by Alfredo García-Debrás, 8 June 1995; MFP 18.000410, 73.55 mm SL, female, Grieta Punta de Guana crevice, Matanzas municipality, North of Matanzas province, Cuba, collected by Gonzalo Abio, Armando Montoto and Erik García-Machado, 9 September 1984; MFP 18.000409, 84.5 mm SL, female, La Pluma cave, Matanzas municipality, North of Matanzas province, Cuba, collected by Gonzalo Abio, 3 October 1986; MFP 18.000411 (2 specimens), 60.95-92.05 mm SL, La Pluma cave, Matanzas municipality, North of Matanzas province, Cuba, collected by Lazaro Joo, José Alvarez and Ignacio Hernández, 25 March 1984; not catalogued (12 specimens), 66.0-103.0 mm SL, Grieta Punta de Guana crevice, Matanzas municipality, North of Matanzas province, Cuba, (collection data unknown).

Remarks. We examined specimens of $L$. simile from the two known localities: the type-locality Grieta Punta de Guana cave (Nalbant, 1981) and La Pluma Cave (DíazPérez et al. 1987a). This species was also reported from El Tunel cave in Quivican, southern Havana, living in sympatry with $L$. dentata (Díaz-Pérez et al. 1987a). However, this later report need verification.

\section{Lucifuga lucayana Møller, Schwarzhans, Iliffe \& Nielsen, 2006}

see Møller et al. (2006).

\section{Lucifuga spelaeotes Cohen \& Robins, 1970}

see Møller et al. (2006). 


\section{Acknowledgments}

We want to thank Pedro Chevalier, Eduardo Abreu, Majorie Condis, Katrine Worsaae, José Alberto Pino Cuenca and Yosvani Medina, for field assistance, and José Luis Ponce de León, Niurka Hernández, Carlos Arredondo, Alfredo García and Arturo Rojas that supplied valuable specimens. Thanks to Isabelle Germon for laboratory assistance. Thanks to technician Mabel Suares for radiographs assistance. We thank Mark Sabaj Perez (ANSP), Caleb McMahan (FMNH), Karsten Hartel (MCZ), Douglas Nelson (UMMZ) and Edda Aßel and Peter Bartsch (ZMB) for providing access to museum material under their care. We thank the Embassy of France in Cuba and the Carlsberg Foundation (grant: 2013_01_0501 to KW and PRM) for financial support during this investigation.

\section{References}

Cohen DM, Robins CR (1970) A New Ophidioid Fish (genus Lucifuga) from a Limestone sink, New Providence Island, Bahamas. Proceeding of the Biological Society of Washington 83: 133-144.

Cohen DM, McKosker JE (1998) A new species of Bythitid Fish, genus Lucifuga, from the Galapagos Island. Bulletin of Marine Science 63: 179-187.

Corella JE, Echtinger H, Guarch JJ (2000) Caracter Sticas Espeleológicas del kast de la region de Gibara (Cuba). Endins, no. 23. Palma de Mallorca.

Díaz-Pérez PA (1988) Lucifuga teresinarum sp. n., Nueva Especie Cubana de Peces Troglobios. (Ophidiiformes, Bythitidae). Revista Biología 2: 37-43.

Díaz-Pérez PA, Lima AM, García E (1987a) Morfología Externa de Ejemplares Machos de Lucifuga simile Nalbant, 1981 (Ophidiiformes, Bythitidae). Revista Biología 1: 77-84.

Díaz-Pérez PA, Nieto E, Abio G (1987b) Peces Ciegos del Género Lucifuga (Ophidiiformes, Bythitidae) en dos Casimbas Cubanas. Revista Investigaciones Marinas 8: 41-47.

Dietz P (2015) Höhlentauchführer Kuba. Tauch-Info und Verlag, Berlin, 148 pp.

Echtinger H (2000) Die caverna de Tanque Azul ein subaqutisches hohlensystem bei Gibara (Cuba). ENDINS no 23. Palma de Mallorca.

Eigenmann CH (1909) Cave vertebrates of America; a study in degenerative evolution. Carnegie Institution, Washington, D.C., 241 pp. https://doi.org/10.5962/bhl.title.11955

Fricke R, Eschmeyer WN, Van der Laan R (2019) ESCHMEYER'S Catalog of Fishes: Genera, Species, References. http://researcharchive.calacademy.org/research/ichthyology/catalog/ fishcatmain.asp [Electronic version accessed 16 May 2019]

García-Debrás A, Pérez A (1999). Estudio sobre la dieta de peces ciegos cubanos (Ophidiiformes: Bythitidae). Troglobio 4: 2-3.

García-Machado E, Hernández D, García-Debrás A, Chevalier-Monteagudo P, Bernatchez L, Casane D (2011) Molecular phylogeny and phylogeography of the Cuban cave-fishes of the genus Lucifuga: Evidence for cryptic allopatric diversity. Molecular Phylogenetic and Evolution 61: 470-483. https://doi.org/10.1016/j.ympev.2011.06.015

Gill TN (1863) Descriptions of the genera of gadoid and brotuloid fishes of western North America. Proceedings of the Academy of Natural Sciences of Philadelphia 15: 242-254. 
Hernández D (2005) Relaciones evolutivas de las especies del genéro Lucifuga (Ophidiiformes: Bythitidae) en Cuba. Centro de Investigaciones Marinas Universidad de la Habana [Master's Thesis].

Hernández D, Casane D, Chevalier-Monteagudo P, Bernatchez L, García-Machado E (2016) Go West: A One Way Stepping-Stone Dispersion Model for the Cavefish Lucifuga dentata in Western Cuba. PLOS ONE 11(4): e0153545. https://doi.org/10.1371/journal. pone. 0153545

Jordan DC, Evermann BF (1896) A check-list of the fishes and fish-like vertebrates of North and Middle America. Report U.S. Fish. Commission for 1895, 584 pp.

Lane HH (1903) The ovarian structures of the viviparous blind fishes, Lucifuga and Stygicola. The Biological Bulletin 6: 38-54. https://doi.org/10.2307/1535811

Lara A, Ponce de León JL, Rodríguez R, Casane D, Côté G, Bernatchez L, García-Machado E (2010) DNA barcoding of Cuban freshwater fishes: evidence for cryptic species and taxonomic conflicts. Molecular Ecological Resources 10: 421-430. https://doi.org/10.1111/ j.1755-0998.2009.02785.x

Møller PR, Schwarzhans W, Nielsen JG (2004) Tuamotuichthys bispinosus, a new genus and species from off Tuamotu Islands, South Pacific Ocean (Ophidiiformes, Bythitidae). Ichthyological Research 51: 146-152. https://doi.org/10.1007/s10228-004-0210-1

Møller PR, Schwarzhans W, Iliffe TM, Nielsen JG (2006) Revision of the Bahamian cavefishes of the genus Lucifuga (Ophidiiformes, Bythitidae), with description of a new species from islands on the Little Bahama Bank. Zootaxa 1223: 23-46. https://doi.org/10.11646/ zootaxa.1223.1.3

Møller PR, Knudsen SW, Schwarzhans W, Nielsen JG (2016) A new classification of viviparous brotulas (Bythitidae) - with family status for Dinematichthyidae - based on molecular, morphological and fossil data. Molecular Phylogenetics and Evolution 100: 391-408. https://doi.org/10.1016/j.ympev.2016.04.008

Nalbant TT (1981) A Study of the Subterranean Species of Lucifuga from Cuba, with the Description of Lucifuga simile sp. n. (Pices, Ophidiiformes, Bythitidae). Résultats des expéditions bio-spéologiques cubano-roumanianes à Cuba, Bucarest, Romania, 185-190.

Nielsen JG, Cohen DM, Markle DF, Robins CR (1999) Ophidiiform Fishes of the World (Order Ophidiiformes). FAO Species Catalogue 18: I-XI + 1-178.

Poey F (1858) Memorias Sobre la Historia Natural de la Isla de Cuba, Acompañadas de Sumarios Latinos y Frases en Francés, Imprenta de Barcina, Habana, 442 pp.

Proudlove G (2019) Subterranean Fishes of the World. An account of the subterranean (hypogean) fishes with a bibliography from 1436. V1.0 Tuesday 25th June 2019. https:// cavefishes.org.uk/

Thinès G, Piquemal (1978) Observations sur les comportements de Lucifuga subterranea Poey (Pisces, Ophidiidae), poisson cavernicole de Cuba. International Journal of Speleology 10: 195-203. https://doi.org/10.5038/1827-806X.10.2.6

Vergara R (1980) Estudio filogenético de los peces ciegos del género Lucifuga (Pisces: Ophidiidae). I. Sistemática Filogenética. Revista CENIC 11: 311-323.

Vergara R (1981) Estudio filogenético de los peces ciegos del género Lucifuga (Pisces: Ophidiidae). II. Bibliografía Filogenética. Revista Ciencias Biológicas, 12: 99-107. 